\title{
Constitutionale
}

Volume 2 Issue 2, July-December 2021: PP: 103-114

Faculty of Law, Universitas Lampung, Bandar Lampung, Indonesia.

http://jurnal.fh.unila.ac.id/index.php/constitutionale

P-ISSN: 2723-2492 E-ISSN: 2745-9322

\section{Implementation of Good Governance through E-Governance in Modern Law Countries during the Covid-19 Pandemic}

\author{
Neillisa Regga Syahputri \\ Universitas Negeri Yogyakarta, Indonesia \\ neillisareggasyahputri@gmail.com \\ Eny Kusdarini \\ Universitas Negeri Yogyakarta, Indonesia \\ enykusdarini@uny.ac.id
}

Submitted: June 3 2021; Reviewed: Aug 9 2021; Accepted: Oct 12, 2021

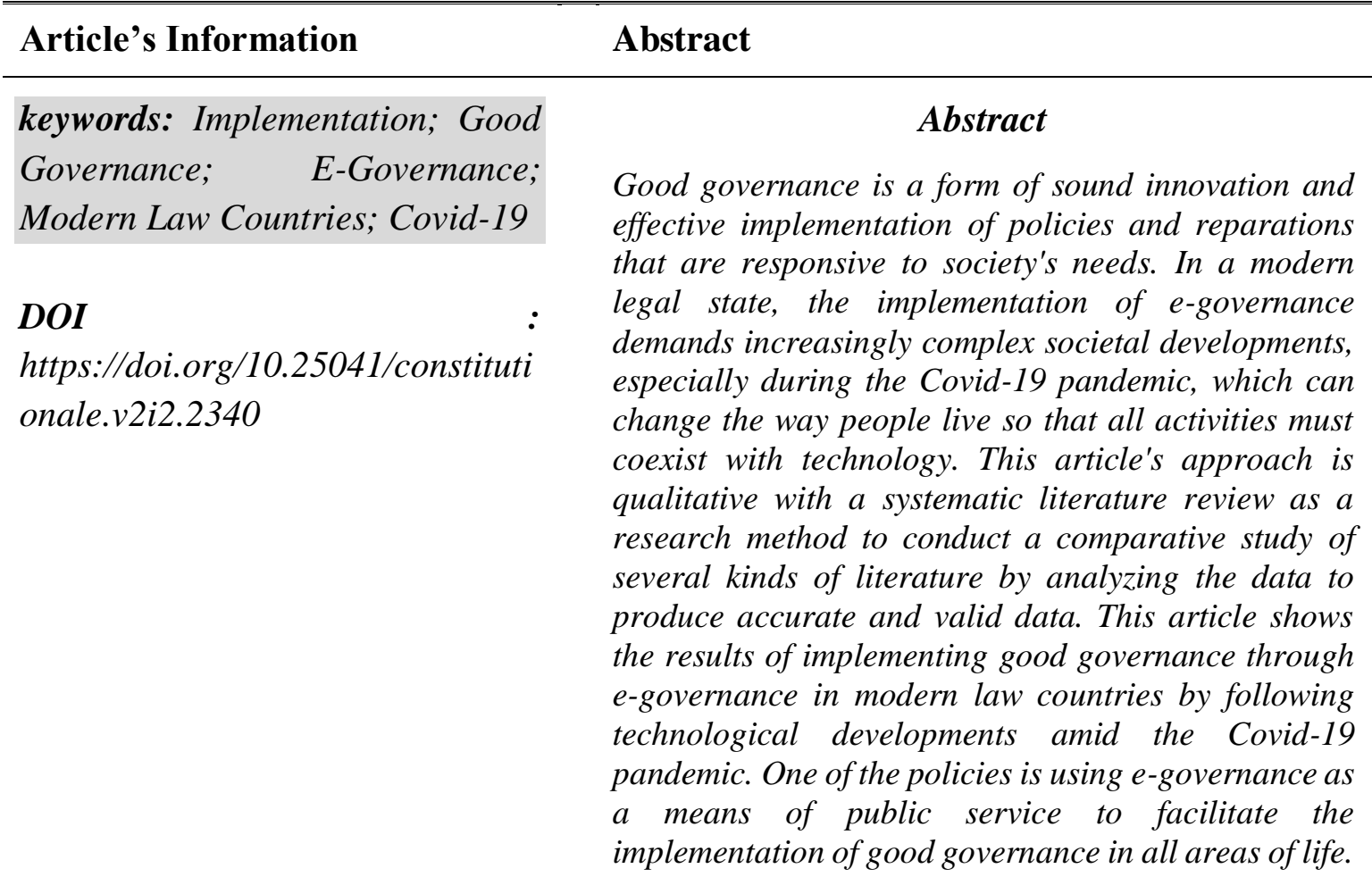




\section{A. Introduction}

The state is an institution that seeks to accommodate individual interests for community life and become collective interests. ${ }^{1}$ A state's definition is the highest organization of people to unite and live together in an area and have a sovereign government. Each country recognizes that law is an essential aspect of life, so that the term the rule of law (rechsstaat) emerged. Initially, the rule of law was created to prevent the government from arbitrary actions that would lead to abuse of power. ${ }^{2}$ Law is considered to exist based on the interactions of various society members, such as national law, traditional law, and legal interactions with many moral considerations until the formation of schools of legal thought. Along with its development, the modern rule of law (modern rechsstaat) appeared when human life entered the modern phase marked by social changes, especially in urban society towards industrial society. Comte argues that the new social order or modernization has the following characteristics: first, the concentration of labour in the centre of urbanization; second, organizing work based on effectiveness and profit; third, there is an application of science and technology in the industrial production process; fourth, the emergence of hidden antagonisms between workers and employers; fifth, the existence of social inequality and injustice; and sixth, the economy has a system based on business and competence that is free and open. ${ }^{3}$

In the modernization era, the law is understood as a system of norms that bind every citizen. The state controls and supervises the law with some formal regulations made and compiled by specific communities and direct access to the state. ${ }^{4}$ Modernity in a constitutional state is characterized by several aspects, such as the law in a written form. The law also applies to state and law areas as an instrument used consciously to realize political decisions in society. ${ }^{5}$ The modern rule of law's concept is a demand from the development of an increasingly complex society and the influence of advances in technology and information that have entered and coloured the concept of law in all parts of the world. For each country, prominent people are still classified as traditional, economically, politically and culturally. Inevitably, they use modern laws. Afterwards, then demand the creation of regulatory norms relevant to the needs of modern society.

The modern rule of law is related to governance. It can be said that a modern rule of law states that its government is not only limited to implementing laws but also contributing to the making of laws. The government has the responsibility to participate in various social activities to achieve state goals actively. The government should carry out activities by the principles of good governance. In general, the beginning of good governance is an order for administering good governance according to state regulations. The Organization for Economic Co-operation and Development (OECD) argues that the government's concept shows political authority and control centres concerning resource management for society's welfare. ${ }^{6}$

\footnotetext{
${ }^{1}$ Samsul Nizar, "Konsep Negara Dalam Pemikiran Politik Ibnu Khaldun,” Demokrasi 2, no. 1 (2003): 95-108.

2 Janpatar Simamora, "Tafsir Makna Negara Hukum Dalam Perspektif Undang-Undang Dasar Negara Republik Indonesia Tahun 1945,” Jurnal Dinamika Hukum 14, no. 3 (September 15, 2014): 547-61, https://doi.org/10.20884/1.JDH.2014.14.3.318.

${ }^{3}$ Piotr Ztompka, Sosiologi Perubahan Sosial (Jakarta: Prenada Media Group, 2007).

${ }^{4}$ Dedy Sumardi, "Islam, Pluralisme Hukum Dan Refleksi Masyarakat Homogen," Asy-Syirah Jurnal Ilmu Syaria'ah Dan Hukum 50, no. 2 (2016): 482-504.

5 Satjipto Raharjo, "Pendidikan Hukum Sebagai Pendidikan Manusia," Jurnal Law Perform 1, no. 1 (2005), https://doi.org/10.14710/lr.v1i1.12176.

${ }^{6}$ Thomas G. Weiss, "Governance, Good Governance and Global Governance: Conceptual and Actual Challenges," Third World Quarterly 21, no. 5 (2000): 795-814, https://doi.org/10.1080/713701075.
} 
Currently, the country is faced with the spread of a viral epidemic that attacks all world regions. Currently, the country is faced with the spread of a viral epidemic that attacks all world regions. At the end of 2019, the WHO (World Health Organisation) obtained information regarding an unknown strain of pneumonia identified in Wuhan, China. ${ }^{7}$ This virus outbreak is known as Corona Virus or Covid-19. Covid-19 is a threat to global health that attacks the respiratory tract. ${ }^{8}$ The emergence of Covid-19 makes life entirely online by utilizing an internet network that forces people to do work from home (WFH) to be an alternative to break the chain of Covid-19 spread. Therefore, in a situation like this, it is necessary to use information technology to make it easier for the public to overcome all the problems in life, especially in government. In the digital era, the government will develop its quality and capacity for society's benefit through e-governance as a form of innovation in government access to public services. E-governance stands for electronic government or electronic governance, which operates on information and communication technology (ICT) to increase the government's potential to meet society's needs. ${ }^{9}$ E-governance is needed since the world is using technological developments, especially amid the Covid-19 pandemic. This situation reduces the community meeting's intensity to take care of all the interests or needs of the community. Problems related to implementing good governance through e-governance are increasingly becoming a substance to consider adequate facilities for the community.

The nation's problems are increasingly complex. Should the practice of good governance be able to run by the principles of good governance? To get this, of course, the government must improve public services. To illustrate this point, in the realm of law, such as corruption, the percentage of corruption will undoubtedly decrease with the creation of just law. However, as we know, currently, the government, especially Indonesia, is still possible to experience a decline, and development is needed in terms of law, culture, and economy. The government will increasingly care about the interests and desires of the public. Gradually our government is in a better situation.

This research aims to determine good governance implementation through e-governance in modern law countries during the coronavirus disease (Covid-19) pandemic. Good governance makes it easier for all citizens to obtain public policies and legal justice to monitor the community, especially during the Covid-19 pandemic. In this case, the state should be able to apply the concepts and principles of good governance in modern law countries implemented in the application of e-governance facilities. This research approach uses qualitative with systematic literature review as a research method to conduct a comparative study of several kinds of literature by analyzing data to produce accurate and valid data.

\section{B. Discussion}

\section{Good Governance during the Covid-19 Pandemic}

The term "good" in the word "good governance" is defined as an understanding of values by upholding the desire of the people and values to be able to increase the capability and ability of the people to achieve a common national goal, including independence, social justice and sustainable development. ${ }^{10}$ Meanwhile, the word "governance" is defined as the process of

\footnotetext{
${ }^{7}$ Min-Hyu Kim et al., "Assessing the South Korean Model of Emergency Management during the COVID-19 Pandemic," Asian Studies Review 44, no. 4 (2020): 567-78, https://doi.org/10.1080/10357823.2020.1779658.

8 Anthony S Fauci, H. Clifford Lane, and Robert R Redfield, "Covid-19-Navigating the Uncharted," The New England Journal of Medicine 382, no. 13 (2020), https://doi.org/10.1056/NEJMe2002387.

${ }^{9}$ Atta Ullah et al., "The Role of E-Governance in Combating COVID-19 and Promoting Sustainable Development: A Comparative Study of China and Pakistan," Chinese Political Science Review 6, no. 1 (2021): 86-118, https://doi.org/10.1007/s41111-020-00167-w.

${ }^{10}$ Komisi Pemberantasan Korupsi, Modul Materi: Good Governance Dan Pelayanan Publik (Jakarta: Direktorat Pendidikan dan Pelayanan Masyarakat, 2016).
} 
decision-making and how decisions can or cannot be implemented. ${ }^{11}$ Governance comes from ancient Latin and Greek, which means control, guidance, and manipulation. Discussions of governance have long overlapped with the word government, especially regarding administrative, legal, and political activities related to society. ${ }^{12}$ The governance functions to implement day-to-day state rules packaged by state organizations formed based on public trust and the state's certainty. Government functions are divided into two types:

1) primary function or service as a public service provider that is both privatized and civil service including bureaucratic services;

2) secondary function or empowerment as development organizer and empowerment programs. ${ }^{13}$

The government will carry out its functions within the framework of good governance if creating a cooperative public administration system with a public service approach that is more relevant to society. ${ }^{14}$ Good governance is likened to a country that impacts other countries regarding an absolute truth of state affairs management.

There are seven criteria for establishing procedures that can implement good governance; the first is legitimacy in bureaucratic institutions or other institutions that are a nongovernmental society. Second, the public has the freedom to express an interest or appreciation from each institution or group of people or stakeholders so that all of these communities can then participate actively in the development process. Third, a form of legal certainty and its enforcement. Fourth, transparency and accountability of the bureaucratic system. Fifth, developr]ed information that can be accessed by the community freely and easily. Sixth, the establishment of public services' effectiveness. Seventh, the creation of good and efficient cooperation between the government and civil society organizations. ${ }^{15}$ Good governance aims to create a good government system that positively impacts all people in all fields. Following the United Nations Development Program (UNDP "Governance and Sustainable Human Development 1997"), a set of principles with slight variation and extensive literature appeared. UNDP categorizes the five basic principles of good governance as follows. ${ }^{16}$

Table 1. Five Principles of Good Governance

\begin{tabular}{|l|l|l|}
\hline $\begin{array}{l}\text { Five principles of } \\
\text { good governance }\end{array}$ & \multicolumn{1}{|c|}{$\begin{array}{c}\text { The UNDP principles and the related UNDP text on } \\
\text { which they are based }\end{array}$} \\
\hline 1 & $\begin{array}{l}\text { Legitimacy } \\
\text { and Voice }\end{array}$ & $\begin{array}{l}\text { Participation: in this principle, all men and women should } \\
\text { contribute their voting rights in making a decision, either } \\
\text { through direct means or through an intermediary institution } \\
\text { that is legitimate and represents an intention for society, } \\
\text { including free speech, constructive participation. } \\
\text { Consensus Orientation: Good governance or good } \\
\text { governance mediates broad consensus about which will be in } \\
\text { the group's best interest, even if possible about a policy } \\
\text { procedure. }\end{array}$ \\
\hline
\end{tabular}

\footnotetext{
${ }^{11}$ United Nations, "No. 30676. United Nations (Economic and Social Commission for Asia and the Pacific) and India," 2000, https://doi.org/10.18356/d4072237-en-fr.

12 Yu Keping, "Governance and Good Governance: A New Framework for Political Analysis," Fudan Journal of the Humanities and Social Sciences, 2018, https://doi.org/10.1007/s40647-017-0197-4.

13 Taliziduhu Ndraha, Ilmu Pemerintahan (Kybernology) (Bandung: PT Rineka Cipta, 2001).

${ }^{14}$ Panji Santosa, Teori Dan Aplikasi Good Governance (Bandung: PT Refika Aditama, 2012).

15 Zulkarnain Ridlwan, "Mekanisme Konsultasi Publik :Instrumen Pembangun Good Governance Di Daerah," FIAT JUSTISIA:Jurnal Ilmu Hukum 6, no. 3 (2015): 1-13, https://doi.org/10.25041/fiatjustisia.v6no3.351.

${ }^{16}$ John Graham, Bruce Amos, and Tim Plumptre, Principles for Good Governance in the 21 st Century (Ottawa: Institute on Governance, 2003).
} 


\begin{tabular}{|c|c|c|}
\hline 2 & Direction & $\begin{array}{l}\text { Strategic Vision: Officials and society have a broad and long- } \\
\text { term perspective regarding good governance and development } \\
\text { for humans, along with what is needed for this development. } \\
\text { Also, there is an understanding of historical, social, and } \\
\text { cultural complexity based on a perspective. }\end{array}$ \\
\hline 3 & Performance & $\begin{array}{l}\text { Responsiveness: Processes as well as institutions that try to } \\
\text { serve all stakeholders. } \\
\text { Effectiveness and Efficiency: Institutions and processes } \\
\text { produce results by meeting needs while making the best use } \\
\text { of resources. }\end{array}$ \\
\hline 4 & Accountability & $\begin{array}{l}\text { Accountability: Decision-makers from government, the } \\
\text { private sector, and civil society organizations are responsible } \\
\text { to society. Then institutional stakeholders and accountability } \\
\text { also differ depending on the organization and whether a } \\
\text { decision comes internally or externally. } \\
\text { Transparency: This principle of transparency is built based } \\
\text { on an autonomous flow of information. In this case, the } \\
\text { process, information, and institutions can be accessed directly } \\
\text { by those involved in this process. Information and institutions } \\
\text { are provided sufficient to understand and monitor the people. }\end{array}$ \\
\hline \multicolumn{2}{|c|}{$\begin{array}{l}\text { Five principles of } \\
\text { good governance }\end{array}$} & $\begin{array}{l}\text { The UNDP principles and the related UNDP text on } \\
\text { which they are based }\end{array}$ \\
\hline 5 & Fairness & $\begin{array}{l}\text { Equality: Men and women have the opportunity to increase } \\
\text { and maintain the happiness and welfare of the people. } \\
\text { Rule of Law: In this framework's principle, the law must be } \\
\text { enforced fairly and impartially, especially in the law regarding } \\
\text { human rights (HAM). }\end{array}$ \\
\hline
\end{tabular}

Source: UNDP revision, 1997.

Good governance is an excellent innovation to improve the quality of people's lives. The implementation of good governance can mitigate the sense of discomfort with public stability, forms of corruption, legal abuse, failure of public services, rampant poverty, and inequality. ${ }^{17}$ Good governance is a form of effective implementation of policies and reparations responsive to its citizens' needs. ${ }^{18}$ Bannett \& Satterfield argue that good governance has normative principles such as recognition, transparency, accountability, communication, participation, consultation, trust, conflict management, legal supremacy, legitimacy, coordination, and collaboration. ${ }^{19}$ This is in line with Soepomo's opinion, which explains that good governance is an appropriate way of carrying out the assigned tasks and being accountable to politics professionally, transparent, responsible, and fair. ${ }^{20}$ Governance is a new paradigm in

${ }^{17}$ Merilee Grindle, "Good Governance: The Inflation of an Idea Faculty Research Working Paper Series," Harvard University, Center for International Development, 2010, 1-20, http://nrs.harvard.edu/urn3:HUL.InstRepos:4448993.

${ }^{18}$ Herlambang P Wiratraman, "Good Governance Dan Pembaruan Hukum Di Indonesia: Refleksi Dalam Penelitian Sosio-Legal," Jurnal Hukum Dan Peradilan 2, no. 1 (2013), https://doi.org/10.25216/jhp.2.1.2013.2134.

${ }^{19}$ Nathan J. Bennett et al., "Local Support for Conservation Is Associated with Perceptions of Good Governance, Social Impacts, and Ecological Effectiveness," Conservation Letters 12, no. 4 (2019), https://doi.org/10.1111/conl.12640.

${ }^{20}$ Projojono Soepomo, Definisi Akuntan Sekotor Publik Dalam Upaya Penciptaan Good Government/Governance (Jakarta: Ikatan Akuntan Indonesia, 2000). 
governance management. This continuous development has made the digital era the main focus as the standard of a developed country. The activities carried out by each community are inseparable from technology, especially when the Covid-19 outbreak in the community makes all public activities assisted by various forms of technology, electronics, and the internet, which cannot be separated from human life. Even though it was appalled by the existence of Covid19 , it is natural for the government to provide innovations to reduce the spread of the epidemic by providing complex good governance services by focusing on accountability and transparency because accountability is the key to all principles of good governance. ${ }^{21}$

Governance consists of three pillars, namely the government, private sector, and society. ${ }^{22}$ In this case, the government is the main subject of implementing good governance. Through the government and all its policies, the state can continue developing itself to adapt to changes and progress and provide convenient access to public services to the entire community. The private sector, such as non-governmental organizations (NGOs), implement good governance. As the manager of resources outside the state and the bureaucracy, the private sector must manage the state structure and community resources. ${ }^{23}$ The state's public sector and the government system are the cornerstones of the service, so citizens must be guaranteed their rights. Then on society, it refers to society's importance in improving service quality and making public policies. In this pillar, public participation in implementing good governance is in line with the new view that is developing to improve citizens' services, not only as customers but also as citizens who own the state and the government (owner) ${ }^{24}$ Good governance can be interpreted as a form of government implementation in a state of law to consider and uphold the people's will according to their needs by providing good services to the development order, legal guarantees, and social justice.

\section{2. -Governance in Modern State of Law Concept}

The rule of law is defined as a set of government officials and citizens bound together to comply with the rule of law. The law's application must be equal to everyone without exceptions by legal rules that each individual violates. ${ }^{25}$ According to Kelsen, the law is the main norm that determines sanctions. ${ }^{26}$ In an important element of the law, these norms then form the legal order. On the other hand, Fuller's opinion regarding the law is that law is not a system of norms but a human activity of lawgivers. ${ }^{27}$

As we know, the law is not fixed and can change. If the law is far from the community and left behind, it can be ascertained that its operation is not optimal, ineffective, and lame. In fact, at this time, the legal function focuses on being a distributor. Law is also often assumed to be effective if the law can direct human behaviour with awareness, which affects the development's success. Therefore, there is a need for mutual agreement between the government and the public so that legal functions can be created and run as they should. Following this, Fuller believes that the law will only be successful if the lawgiver puts forward 8 principles of legality in making a legal rule, as follows:

21 Noverman Duadji, "Good Governance Dalam Pemerintahan Daerah," MIMBAR: Jurnal Sosial Dan Pembangunan 2, no. 2 (2012), https://doi.org/10.29313/mimbar.v28i2.356.

${ }^{22}$ Santosa, Teori Dan Aplikasi Good Governance.

23 Juanda Nawawi, "Membangun Kepercayaan Dalam Mewujudkan Good Governance," GOVERNMENT : Jurnal Ilmu Pemerintahan 2, no. 1 (2016): 19-30, http://journal.unhas.ac.id/index.php/government/article/view/1130.

24 Agus Dwiyanto, Mewujudkan Good Governance Melalui Pelayanan Publik (Yogyakarta: Gadjah Mada University Press, 2008).

${ }^{25}$ Brian Z. Tamanaha, “The History and Elements of the Rule of Law," Singapore Journal of Legal Studies, no. 12 (2012): 232-47, https://doi.org/10.2139/ssrn.2255262.

${ }^{26}$ Jack P Gibbs, "Definition of Law and Empirical Questions," Journal of the Law and Society Association 2, no. 3 (1968), https://doi.org/10.2307/3052897.

27 David Luban, "The Rule of Law and Human Rights," Cambridge University Hague Journal on the Rule of Law 2, no. 1 (2010): 29-47, https://doi.org/10.1017/S1876404510100025. 
1) General: the law here must take general rules or clear regulations first.

2) Publicity: laws must be published and must not be kept secret.

3) Clarity: the law must be understandable, clear, detailed, not too vague, and understood by the public.

4) Consistency: laws must not conflict with each other.

5) Feasibility: the law must allow people to comply with a legal policy. In short, between any existing rules, there should be no form of conflict between these regulations.

6) Persistence: the law must not change too quickly. The prevailing regulations must be fixed and not allowed to be changed continuously.

7) Prospectivity: the law cannot be retroactive.

8) Conformity: the law must be administered and enforced as written. ${ }^{28}$

The study of the rule of law (rechtsstaat) developed in continental Europe. The idea of the rule of law was known in the Anglosaxon countries from the 19th century to the early 20th century, namely classical law states (formal) and material law states or modern legal states that called the modern welfare state. ${ }^{29}$ Max Weber explains the characteristics of modern law, which include: first, modern law has a normative quality with an abstract and general form; second, positive law is modern law, meaning that the results of the decision are consciously taken and carried out; third, modern law is strengthened by a form of force which is coercive from a country as a form of sanction which is also deliberately given, concerning various applicable legal rules of courts and various violations of these rules; fourth, the nature of modern law is systematic, covering principles, rules, and concepts with different doctrines. The procedural law section has various materials, which are closely related to each other. It appears that logical and rational normative thinking is based on legal and practical problems, which are then resolved by law. Modern law is secular. Its substance is separate from religious and ethnic views. The validity part does not depend on morality, nor is the procedure independent of the magical definition, which has become a form of a national effort to achieve such an objective. ${ }^{30}$

From the description of Weber's characteristics, it can be concluded that modern law has a written form, meaning that modern law means that it contains rules with a monotonous nature and does not appear to be a variation in them. These rules are more territorial in general, more general territorial than specifically (private). These rules are applied to society members without exception, from various ethnicities, religions, races, classes, regions, cultures, economies, and even gender.

Based on this, a substance emerges where the modern legal state must develop legal policies that can be utilized by the community, such as the existence of E-governance. E-governance consists of information and communication technology (ICT) to support public services, government administration, democratic processes and relations between citizens, civil society, the private sector and the state. ${ }^{31}$ The application of E-governance in a modern legal state can be likened to a mutually sustainable unit; a modern state requires updating public policies by using technology. Modern law aims to maintain security and carry out the government's welfare and justice by the government (bestuurszorg). ${ }^{32}$

\footnotetext{
${ }^{28}$ Luban.

29 Muhammad Alim, Asas-Asas Negara Hukum Modern Dalam Islam: Kajian Komprehensif Islam Dan Ketatanegaraan (Yogyakarta: Pelangi aksara, 2010).

${ }^{30}$ Nasarudin Umar, "Konsep Hukum Modern: Suatu Perspektif Keindonesiaan, Integrasi Sistem Hukum Agama Dan Sistem Hukum Nasional," Walisongo: Jurnal Penelitian Sosial Keagamaan 22, no. 1 (2014): 157, https://doi.org/10.21580/ws.2014.22.1.263.

${ }^{31}$ Frank Bannister and Regina Connolly, "Defining E-Governance 1," E-Service Journal 8, no. 2 (2016): 3-25, https://doi.org/10.2979/eservicej.8.2.3.

32 I Dewa Ayu Widyani, "Kebebasan Bertindak Administrasi Negara Dalam Negara Hukum Modern," To-Ra 4, no. 1 (2018): 39, https://doi.org/10.33541/tora.v4i1.1172.
} 


\section{Implementation of Good Governance through E-Governance in Modern Law Countries during the Covid-19 Pandemic}

The Indonesian state is a country that adheres to a modern legal concept that emphasizes the role and function of dynamic and stable law to regulate all interests in the country without leaving justice as its basic idea. Modern law contains demands for upholding justice and legal protection for the community as necessary in law enforcement, especially in Indonesia. The Indonesian government sees the state of Indonesia as a modern legal state, which continues to strive to maintain community stability by upholding and fighting for legal justice for all levels of society in Indonesia without exception. The fundamental problems related to the government system are the trigger for making the government system more adequate in terms of facilities. One of them is done by implementing governance, which is believed to eradicate corruption, nepotism, bureaucracy, and if done with reasonable procedures, transparency and accountability will effectively reduce poverty. ${ }^{33}$

Every citizen has the right to have political, civil, and human rights (HAM) to meet his life needs. Respecting the rule of law is good for citizens to create a sense of trust in a justice system that can protect them from arbitrary policies and violations of their rights. ${ }^{34}$ Institute on governance describes the things needed to implement good governance, such as: ${ }^{.35}$

1) Having a cooperation framework between organizations, departments, and regions;

2) Having a partnership relationship between the government and every element in the community concerned;

3) Understanding and commitment to responsibility, cooperation, and synergy in achieving goals;

The existence of public administration services that are community-oriented, easy to reach, and communicative have principles based on equity and justice in every action that is carried out, focus on society's interests, behave professionally, and be impartial.

The modern rule of law has a foundation of good governance, democracy, and the rule of law. This foundation refers to forming a state structure with state institutions, the position of government institutions with citizens, and the norms between the government and citizens. ${ }^{36}$ The Modern rule of law states that the law conditions the implementation of good governance. State subjects should not be treated arbitrarily by the authorities, and citizens' rights are protected by law. Good governance has developed at the national, regional, international, and local levels by the problems between government institutions and government and society. The steps in implementing good governance in modern countries are following UNDP's idea, namely:

(a) appreciating the government's potential inequitable development to create good governance;

(b) convincing partners of mutual mistrust and respect;

(c) creating consensus on the core principles of the partnership, applies formally to the partnership and takes special responsibility;

(d) establish a structured multidisciplinary revenue plan and mobilize progress on resources;

(e) review city revenue while continuously mobilizing new resources;

(f) evaluate results and improve management tools for improved governance and partnerships;

\footnotetext{
33 Ved P. Nanda, "The 'Good Governance' Concept Revisited," The ANNALS of the American Academy of Political and Social Science 603, no. 1 (2006): 269-83, https://doi.org/10.1177/0002716205282847.

${ }^{34}$ Eric Neumayer, The Pattern of Aid Giving: The Impact of Good Governance on Development Assistance (New York: Routledge, 2003).

${ }^{35}$ Santosa, Teori Dan Aplikasi Good Governance.

${ }^{36}$ Henk Addink, Good Governance: Concept and Context (New York: Oxford University Press, 2019).
} 
(g) organize systems to acquire knowledge, skills, and regular information;

(h) review procedures and revise laws for the success of good governance;

(i) establish a systematic performance evaluation framework;

(j) improving good governance practices.

Looking at the current worrying situation amid the Covid-19 outbreak, which has attacked all human life sectors and made life arrangements slowly change, knowledge-based information technology must be promoted to all communities. Apart from providing comfort and ease of access, it also aims to prevent people from crowding around. WHO (World Health Organization) states that the Covid-19 outbreak is an emergency epidemic that attacks public health. ${ }^{37}$ So people must be aware of reducing the intensity of leaving the house and carrying out social distancing and physical distancing.

One of the government's innovations to minimize problems in the Covid-19 pandemic is by using e-governance. E-governance is a government platform that uses technology to achieve good governance by providing services and sharing information at minimum costs. Egovernment can interact with citizens and government officials and make the government system more transparent be relied on by the public. E-governance aims to improve information and as a service delivery institution to the public sector. ${ }^{38}$ E-governance has been mandated through Presidential Instruction of the Republic of Indonesia Number 3 of 2003 concerning national policies and e-government development strategies. In this context, e-governance is understood as a form of government performance to facilitate all effective, efficient, transparent accountability in disseminating information to the public sector and other institutions and play a role in implementing government administration activities using electronic media. ${ }^{39}$

The concept of e-governance seeks to create structures and processes by utilizing information and communication technology (ICT) at various government and public sectors to increase the success of good governance. ${ }^{40}$ Atta argues that e-governance can minimize corruption, increase transparency, increase convenience, and increase gross domestic product (GDP). ${ }^{41}$ However, it is not impossible that in every change, even though there will undoubtedly be pros and cons from various parties in the context of improvement, it can be from the public sector, the private sector, and even from the government itself. This happens because the policy's implementation has not been perfect so that it must be continuously reviewed and considered the implementation structure. In addition, the use of e-governance from the citizens and the government's perspectives makes it possible with a fairly complex system to integrate the implementation of services. Providing government documents needed by the community electronically without having to provide physical form, where during the current covid-19 pandemic, this is the way to go. best to avoid crowds and direct virus spread. ${ }^{42}$

There has been a public reaction, such as doubts about the effectiveness of using egovernance, considering that this is a reform in the realm of government. Therefore, reforms

\footnotetext{
${ }^{37}$ Abdul Waris et al., "A Comprehensive Study of SARS-CoV-2 : From 2019-NCoV to COVID-19 Outbreak," Journal Pre-Proof 48, no. 3 (2020): 252-66, https://doi.org/10.1016/j.nmni.2020.100681.

${ }^{38}$ Fatemeh Mohammad Ebrahimzadeh Sepasgozar et al., "Technology Acceptance in E-Governance: A Case of a Finance Organization," Journal of Risk and Financial Management 13, no. 7 (2020): 138, https://doi.org/10.3390/jrfm13070138.

${ }^{39}$ Herri Setiawan and Puwo Santoso, "Model Optimalisasi Peluang Pemanfaatan Media Jejaring Sosial Dalam Implementasi E-Governance Di Indonesia," Jurnal Informatika. UPN “Veteran” Yogyakarta. 2013, no. semnasIF (2013): 147-54.

${ }^{40}$ Okut-Uma, Rogers W'O, and C.S \& London, Electronik Governance: Re-Inventing Good Governance (London: Commonwealth Secretariat, 2000).

${ }^{41}$ Ullah et al., "The Role of E-Governance in Combating COVID-19 and Promoting Sustainable Development: A Comparative Study of China and Pakistan."

${ }^{42}$ Bannister and Connolly, "DEFINING E-GOVERNANCE 1."
} 
are needed that can help and increase public trust to create good governance. The benefits of implementing e-governance for citizens are;

1. An inclusive governance platform that builds trust between the government and citizens by involving citizens in the policy process so that transparency and accountability by the government emerge.

2. The fulfilment of easy and fast access to facilitate various information to every citizen.

3. High efficiency and effectiveness of public services as measured by the quality of interaction between the government and citizens.

4. Cost savings in running the government. The media of e-governance can reduce excessive government spending because most of the data needed are available on egovernment and e-governance systems. This innovation helps the government realize the savings that are needed previously; it cost a lot.

E-governance is sustainable with e-democracy and e-government. E-democracy is intended as an innovation from a democratic system to support citizen participation to help create good governance. According to Kneuer, e-democracy is a general concept about citizens and their contribution to the government. ${ }^{43}$ E-democracy refers to a process and structure covering all electronic communication forms between voters (the community) and the elected (government). ${ }^{44}$ Meanwhile, e-government is a government innovation in information services through technology as a form of service to society. In general, e-government is conceptualized as using technology by incorporating organizational change to improve the government's operating structure in the state wage relationship. ${ }^{45}$ Therefore, e-government and e-democracy are essential components of e-governance because they create good governance. Furthermore, Nurhadryani illustrates the relationship between the three in the following figure. ${ }^{46}$

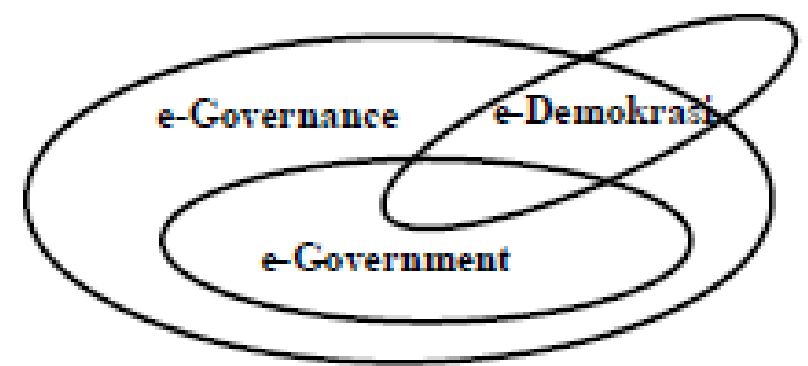

The use of electronics during the Covid-19 pandemic is needed for the public to get to know the online platform better than that as a prevention of the development of the Covid-19 virus outbreak, which can attack anyone. In Indonesia, it is currently confirmed that Covid-19 has reached 700,097 cases with 108,946 active cases, 570,304 people recovered, and 20,847 died. ${ }^{47}$ So that from all sectors, work are performed through an online platform.

In implementing good governance in a modern rule of law as a form of awareness of the dangers of the current covid-19 outbreak, various scientific fields have begun to shift and rely on technology by utilizing electronics as their support. In the political field, as already mentioned, e-democracy as a forum for interaction for government and society is used as an innovation in increasing citizen participation in politics. Currently, national and international

\footnotetext{
43 Marianne Kneuer, "E-Democracy: A New Challenge For Measuring Democracy," International Political Science Review 37, no. 5 (2016), https://doi.org/10.117/0192512116657677.

${ }^{44}$ Okut-Uma, W'O, and \& London, Electronik Governance: Re-Inventing Good Governance.

45 Jean Damascene Twizeyimana and Annika Andersson, "The Public Value of E-Government - A Literature Review," Government Information Quarterly 36, no. 2 (2019): 167-78, https://doi.org/10.1016/j.giq.2019.01.001. 46 Yani Nurhadryani, "Memahami Konsep E-Governance Serta Hubungannya Dengan E-Government Dan EDemokrasi," Seminar Nasional Informatika 2009, no. semnasIF (2009): 111-17.

47 Satuan Tugas Penanganan Covid-19, "Peta Sebaran Covid-19 Indonesia," 2020, https://covid-19.go.id/petasebaran.
} 
banks have provided convenience with e-banking consisting of mobile banking and internet banking in the economic sector. Also, the emergence of shopping applications (e-commerce) such as Shopee, Lazada, Tokopedia, and others can reduce the intensity of leaving the house to transact at banks and shop for people's needs Covid-19 pandemic. In law, one of the ways is the application of e-court, which is enforced in the Supreme Court Regulation No.1 of 2019 concerning the Administration of Cases and Trials in Courts Electronically. This is why the legal sector has also shifted to electronic media, considering the unfavourable situation to carry out trials. Then, in education, online learning or distance learning calls have been enforced during the incessant Covid-19 cases in Indonesia, for some time requiring students to take lessons from home using various media such as google classroom, google Meet, zoom, and others. Good governance is needed to improve citizens' quality of life to achieve common goals between the government and society in a modern rule of law. The era of modernization with the current situation requires various public sectors, governments, and non-governmental organizations (NGOs) to be more innovative in using technology. Its use can be beneficial for the progress of the nation and state.

\section{Conclusion}

With the emergence of a new state law paradigm, administrators demanded good governance considering the current situation, which must coexist with Covid-19. The government in a modern law state seeks to open up new intellectuals by providing concepts to solve public problems and reform justice and the state's contribution in implementing good governance. As the country develops towards modernization, it encourages significant changes in various aspects of the nation and state. The implementation of good governance is essentially intended to realize state administration that is active in wholeness and solidarity is responsible, efficient, and effective. In a modern state of law, its application aims to reform the law and uphold justice for a society without exception. Therefore, using technology with e-governance innovation is believed to help implement clean, fair, transparent, and accountable governance. Moreover, it aims to people's welfare by providing legal protection for government activities in a country that applies in all life areas.

\section{Bibliography}

\section{A. Journal}

Bannister, Frank, and Regina Connolly. "Defining E-Governance 1.” E-Service Journal 8, no. 2 (2016): 3-25. https://doi.org/10.2979/eservicej.8.2.3.

Bennett, Nathan J., Antonio Di Franco, Antonio Calò, Elizabeth Nethery, Federico Niccolini, Marco Milazzo, and Paolo Guidetti. "Local Support for Conservation Is Associated with Perceptions of Good Governance, Social Impacts, and Ecological Effectiveness." Conservation Letters 12, no. 4 (2019). https://doi.org/10.1111/conl.12640.

Duadji, Noverman. "Good Governance Dalam Pemerintahan Daerah.” MIMBAR: Jurnal Sosial Dan Pembangunan 2, no. 2 (2012). https://doi.org/10.29313/mimbar.v28i2.356.

Fauci, Anthony S, H. Clifford Lane, and Robert R Redflied. "Covid-19-Navigating the Uncharted." The New England Journal of Medicine 382, no. 13 (2020). https://doi.org/10.1056/NEJMe2002387.

Gibbs, Jack P. "Definition of Law and Empirical Questions." Journal of the Law and Society Association 2, no. 3 (1968). https://doi.org/10.2307/3052897.

Grindle, Merilee. "Good Governance: The Inflation of an Idea Faculty Research Working Paper Series." Harvard University, Center for International Development, 2010, 1-20. http://nrs.harvard.edu/urn-3:HUL.InstRepos:4448993. 
Keeping, Yu. "Governance and Good Governance: A New Framework for Political Analysis." Fudan Journal of the Humanities and Social Sciences, 2018. https://doi.org/10.1007/s40647-017-0197-4.

Kim, Min-Hyu, Wonhyuk Cho, Hemin Choi, and Joon-Young Hur. "Assessing the South Korean Model of Emergency Management during the COVID-19 Pandemic." Asian $\begin{array}{llllll}\text { Studies } & \text { Review } & \text { (2020): } & \text { 567-78. }\end{array}$ https://doi.org/10.1080/10357823.2020.1779658.

Kneuer, Marianne. "E-Democracy: A New Challenge For Measuring Democracy." International Political Science Review 37, no. 5 (2016). https://doi.org/10.117/0192512116657677.

Luban, David. "The Rule of Law and Human Rights." Cambridge University Hague Journal on the Rule of Law 2, no. 1 (2010): 29-47. https://doi.org/10.1017/S1876404510100025.

Mohammad Ebrahimzadeh Sepasgozar, Fatemeh, Usef Ramzani, Sabbar Ebrahimzadeh, Sharifeh Sargolzae, and Samad Sepasgozar. "Technology Acceptance in E-Governance: A Case of a Finance Organization.” Journal of Risk and Financial Management 13, no. 7 (2020): 138. https://doi.org/10.3390/jrfm13070138.

Nanda, Ved P. "The 'Good Governance' Concept Revisited." The ANNALS of the American Academy of Political and Social Science 603, no. 1 (2006): 269-83. https://doi.org/10.1177/0002716205282847.

Nawawi, Juanda. "Membangun Kepercayaan Dalam Mewujudkan Good Governance." GOVERNMENT: Jurnal Ilmu Pemerintahan 2, no. 1 (2016): 19-30. http://journal.unhas.ac.id/index.php/government/article/view/1130.

Nizar, Samsul. "Konsep Negara Dalam Pemikiran Politik Ibnu Khaldun.” Demokrasi 2, no. 1 (2003): 95-108.

Nurhadryani, Yani. "Memahami Konsep E-Governance Serta Hubungannya Dengan EGovernment Dan E-Demokrasi." Seminar Nasional Informatika 2009, no. semnasIF (2009): 111-17.

Raharjo, Satjipto. "Pendidikan Hukum Sebagai Pendidikan Manusia." Jurnal Law Perform 1, no. 1 (2005). https://doi.org/10.14710/lr.v1i1.12176.

Ridlwan, Zulkarnain. "Mekanisme Konsultasi Publik:Instrumen Pembangun Good Governance Di Daerah." FIAT JUSTISIA:Jurnal Ilmu Hukum 6, no. 3 (2015): 1-13. https://doi.org/10.25041/fiatjustisia.v6no3.351.

Setiawan, Herri, and Puwo Santoso. "Model Optimalisasi Peluang Pemanfaatan Media Jejaring Sosial Dalam Implementasi E-Governance Di Indonesia." Jurnal Informatika. UPN "Veteran" Yogyakarta. 2013, no. semnasIF (2013): 147-54.

Simamora, Janpatar. "Tafsir Makna Negara Hukum Dalam Perspektif Undang-Undang Dasar Negara Republik Indonesia Tahun 1945." Jurnal Dinamika Hukum 14, no. 3 (September 15, 2014): 547-61. https://doi.org/10.20884/1.JDH.2014.14.3.318.

Sumardi, Dedy. "Islam , Pluralisme Hukum Dan Refleksi Masyarakat Homogen." Asy-Syirah Jurnal Ilmu Syaria'ah Dan Hukum 50, no. 2 (2016): 482-504.

Tamanaha, Brian Z. "The History and Elements of the Rule of Law." Singapore Journal of Legal Studies, no. 12 (2012): 232-47. https://doi.org/10.2139/ssrn.2255262.

Twizeyimana, Jean Damascene, and Annika Andersson. "The Public Value of E-Government - A Literature Review." Government Information Quarterly 36, no. 2 (2019): 167-78. https://doi.org/10.1016/j.giq.2019.01.001.

Ullah, Atta, Chen Pinglu, Saif Ullah, Hafiz Syed Mohsin Abbas, and Saba Khan. "The Role of E-Governance in Combating COVID-19 and Promoting Sustainable Development: A Comparative Study of China and Pakistan." Chinese Political Science Review 6, no. 1 (2021): 86-118. https://doi.org/10.1007/s41111-020-00167-w.

Umar, Nasarudin. “Konsep Hukum Modern: Suatu Perspektif Keindonesiaan, Integrasi Sistem 
Hukum Agama Dan Sistem Hukum Nasional." Walisongo: Jurnal Penelitian Sosial Keagamaan 22, no. 1 (2014): 157. https://doi.org/10.21580/ws.2014.22.1.263.

Waris, Abdul, Muhammad Ali, Atta Ullah Khan, Asmat Ali, and Abdul Baset. "A Comprehensive Study of SARS-CoV-2 : From 2019-NCoV to COVID-19 Outbreak." Journal Pre-Proof 48, no. 3 (2020): 252-66. https://doi.org/10.1016/j.nmni.2020.100681.

Weiss, Thomas G. "Governance, Good Governance and Global Governance: Conceptual and Actual Challenges." Third World Quarterly 21, no. 5 (2000): 795-814. https://doi.org/10.1080/713701075.

Widyani, I Dewa Ayu. "Kebebasan Bertindak Administrasi Negara Dalam Negara Hukum Modern.” To-Ra 4, no. 1 (2018): 39. https://doi.org/10.33541/tora.v4i1.1172.

Wiratraman, Herlambang P. "Good Governance Dan Pembaruan Hukum Di Indonesia: Refleksi Dalam Penelitian Sosio-Legal.” Jurnal Hukum Dan Peradilan 2, no. 1 (2013). https://doi.org/10.25216/jhp.2.1.2013.21-34.

\section{B. Books}

Addink, Henk. Good Governance: Concept and Context. New York: Oxford University Press, 2019.

Alim, Muhammad. Asas-Asas Negara Hukum Modern Dalam Islam : Kajian Komprehensif Islam Dan Ketatanegaraan. Yogyakarta: Pelangi aksara, 2010.

Dwiyanto, Agus. Mewujudkan Good Governance Melalui Pelayanan Publik. Yogyakarta: Gadjah Mada University Press, 2008.

Graham, John, Bruce Amos, and Tim Plumptre. Principles for Good Governance in the 21st century. Ottawa: Institute on Governance, 2003.

Komisi Pemberantasan Korupsi. Modul Materi: Good Governance Dan Pelayanan Publik. Jakarta: Direktorat Pendidikan dan Pelayanan Masyarakat, 2016.

Ndraha, Taliziduhu. Ilmu Pemerintahan (Kybernology). Bandung: PT Rineka Cipta, 2001.

Neumayer, Eric. The Pattern of Aid Giving: The Impact of Good Governance on Development Assistance. New York: Routledge, 2003.

Okut-Uma, Rogers W'O, and C.S \& London. Electronic Governance: Re-Inventing Good Governance. London: Commonwealth Secretariat, 2000.

Santosa, Panji. Teori Dan Aplikasi Good Governance. Bandung: PT Refika Aditama, 2000.

Soepomo, Projojono. Definisi Akuntan Sekotor Publik Dalam Upaya Penciptaan Good Government/Governance. Jakarta: Ikatan Akuntan Indonesia, 2000.

Ztompka, Piotr. Sosiologi Perubahan Sosial. Jakarta: Prenada Media Group, 2007.

\section{Regulations}

Supreme Court No. 1/2019 concerning Case Administration and Trial in Electronic Courts

\section{Internet}

Satuan Tugas Penanganan Covid-19. "Peta Sebaran Covid-19 Indonesia," 2020. https://covid19.go.id/peta-sebaran.

Nations, United. "No. 30676. United Nations (Economic and Social Commission for Asia and the Pacific) and India," 2000. https://doi.org/10.18356/d4072237-en-fr. 